\title{
APPROACHES AND. PROGRESS WITH LAND REFORM IN SOUTH AFRICA
}

\author{
J.F. Kirsten and J. van Zyl
}

\section{INTRODUCTION}

The skewed distribution of land ownership along racial lines within the countries of Southern Africa is well known. This is particularly true for South Africa, where the racial policies of 'A partheid' and agricultural policies aimed at national food self-sufficiency created an agricultural structure dominated by large, mechanised farms that are owned and operated by a small number of individuals or companies. As a result of this history of distortion, this minority owns more than $\mathbf{8 0}$ per cent of South Africa's agricultural land (see, among others, Mbongwa et al., 1996 and Kirsten \& Van Zyl, 1996).

This reality provides sufficient motivation for land reform in South Africa. In addition it can be argued that, provided land reform is correctly implemented, it can contribute to increased efficiency and equity, increased growth and poverty reduction. While each of these provides a good case for redistributive land reform, together they make a compelling argument (Van Zyl et al., 1996). The South African Government adopted a Land Reform Programme in 1994 with the ambitious target of redistributing 30 per cent of the total agricultural land area within a period of five years. The theoretical work underpinning this Programme clearly shows that international experience holds strong lessons for the design of such a programme. These lessons were acknowledged and taken on board when the South African Land Reform Programme was designed. It was argued that, in implementing land reform, South Africa should avoid the costly mistakes of land reform programmes in other countries.

Despite these sound intentions, this paper shows that the land reform programme has already made many of the same mistakes it initially tried to avoid. The paper discusses aspects of the approach and progress of the South African Land Reform Programme. In particular, it measures the progress of land reform to date, and discusses the extent to which the international experience has been incorporated in the design. The structure of the paper is

1 Department of Agricultural Economics, Extension and Rural Development, University of Pretoria, South Africa. 
as follows. The next section briefly summarises the lessons from international experience with land reform. This is followed by a discussion of the approach followed in the Programme, and a section on the progress made to date. The conclusion addresses the question: What went wrong?

\section{LESSONS FROM INTERNATIONAL EXPERIENCE WITH REDISTRIBUTIVE LAND REFORM}

In order to asses the performance of the land reform programme in South Africa it is necessary to pose momentarily and reflect on the international experience with land reform. The five salient lessons to emerge from international experiences in land reform are summarised by Christiansen (1996) as follows:

- The speed of implementation of the programme. One characteristic of a successful programme is rapid implementation. In the absence of fast paced programmes, a combination of excessive bureaucracy, overcentralisation of the process and legal challenges is likely to render the programme ineffective.

- Economic viability of the farm models. Before a reform programme is implemented, there must be a careful assessment of the models or livelihood options available to rural households. That is, the models should indicate whether the persons resettled on the land have sufficient land size and quality to provide at least the target income. Further, in computing the costs and benefits, other assistance and infrastructure necessary to generate the income should be planned.

- Political acceptability and legitimacy of the programme. There must be a consensus across the spectrum of political opinion that the programme is both necessary and the most acceptable way of achieving the stated goals. Land reform programmes are not irreversible, particularly where this consensus has not been achieved.

- Clear definition of the role that the public sector can and will play. The proposed programme must be evaluated in light of an understanding and acceptance of the roles that the public sector can and must play, and what should be best left to the non-governmental sector. Programmes that have relied entirely on the public sector in the belief that it is the only one capable of maintaining integrity, delivering services, determining needs, and managing the process have been failures. 
- Land reform is only one part of a comprehensive programme of economic reconstruction. The redistribution of land is necessary, but not sufficient to guarantee the success of a development programme. There is the need for additional services - infrastructure, markets, incentives, health - to be considered and access provided. These considerations are necessary both to sustain higher productivity subsequent to reform and to include others who may not benefit from the direct provision of land.

It is in the light of these lessons that it is generally accepted that marketassisted land redistribution programmes tend to perform better than those administered and operated by the public sector. The need for reliance on market mechanisms stems from the observed weaknesses of non-market oriented programmes that typically vest too much control in public sector bureaucracies. These public sector bureaucracies develop their own set of interests that are in conflict with the rapid redistribution of land (Kinsey \& Binswanger, 1993). Nonetheless, a well-functioning land market is not a sufficient condition for large mechanised and relatively inefficient farms to be subdivided into smaller family-type farms, specifically where economic and institutional distortions favour large farms over small farms. Therefore, nonmarket interventions in the form of grants are necessary to ensure successful implementation of any land reform programme. Executing land reform through grants or vouchers to beneficiary groups who buy from willing sellers obviates the need for a land reform/settlement agency and chances for bureaucratic rent seeking are therefore less. Beneficiaries are free to choose the land in the market and do with it what they wish, rather than having to follow the guidelines of an agency. The cost and delays of expropriation proceedings are avoided. It appears, therefore, that expropriation - even at market prices should only be used as a last resort.

Reliance on the willing buyer - willing seller model will greatly reduce the political opposition to land reform and may increase its political sustainability over the decade or so required to implement any sizeable programme (Binswanger, 1996). It is evident that market-assisted land reform and expropriation with compensation at market prices seems to have several advantages: (a) a more poorly organised coalition of beneficiaries may be able to win approval at the legislative stage; (b) the annual budget process for funding the grants can rely on a broader and more focused coalition of supporters; and, (c) market prices can be influenced by policies which eliminate the privileges of the large-scale sector.

A prerequisite for any market-assisted land reform programme is the removal of policy distortions favouring relatively large farms over smaller farms (levelling 
the playing field), and driving up land prices to levels well above the capitalised value of future farm profits. This is important for two reasons: (a) high land market prices relative to the capitalised value of future farm profits will increase the cost of a reform programme, will serve as an incentive for the selling of farms by beneficiaries to get windfall profits (see Carter and Mesbah, 1993 on reservation prices), will limir the supply of land to beneficiaries, and will encourage land purchases by groups other than beneficiaries, for example, good farmers and business people looking for tax shelters; and (b) measures favouring relatively large farms over smaller farms lower the reservation prices of small farmers who are often poor, thereby encouraging the selling of land by beneficiaries and the purchase of land by groups other than beneficiaries.

Fortunately, today it can be stated that the agricultural policy environment in South Africa is conducive to market-assisted land reform. The policy environment has become much more liberalised since the early 1980s, with most of the privileges to large farms having been abolished, or in the process of being abolished (Kirsten \& Van Zyl, 1996). This has paved the way for better functioning markets with fewer distortions, and a general agricultural environment that is conducive to market-assisted land reform.

\section{THE APPROACH FOLLOWED IN REDISTRIBUTING FARM LAND IN SOUTH AFRICA}

Much of the theoretical research (documented in Van Zyl et al., 1996) for the preparation and design of land reform programme has taken the lessons and principles discussed above on board. As a result the land reform process in South Africa has largely adopted the ideology and guidelines outlined earlier. A pilot land reform programme was designed (Lund, 1996) following more or less the guidelines of the market-assisted approach. The pilots were implemented to test potential delivery mechanisms of land to the beneficiaries.

The Land Reform Programme of the South African Government has three focus areas, namely restitution of land rights to the victims of forced removals, redistribution of land to the disadvantaged and tenure reform aimed at promoting security of tenure for all. For land redistribution as much as possible will be relied upon the existing land market through a process of market-assisted redistribution. However, a number of other options are pursued outside the Government's programme, which are also contributing to the objective of a more equitable distribution of farm land. These are also addressed in this section. 
In order to manage the land reform process a number of laws have been passed since 1994. Although it is not contained in a single national legislative framework, as was suggested by Klug (1996), it covers most of the elements of such a comprehensive framework. The relevant legislation is:

- Restitution of Land Rights Act, No. 22 of 1994

- Land Administration Act, No. 2 of 1995

- Land Reform (Labour tenants) Act No.3 of 1996

- Upgrading of Land Tenure Rights Act, 1991 as amended by Act No. 34 of 1996

- Interim Protection of Informal Land Rights Act, No. 31 of 1996

- Communal Property Associations Act, No. 28 of 1996.

The legislation listed above supports the three cornerstones of the land reform process, i.e. restitution, redistribution and tenure reform. In addition, it was also introduced to create a viable system of land administration. Some of the legislation specifically supported the market-assisted land redistribution process. The Communal Property Associations Act, for example, was enacted to enable communities to form jurist persons, to acquire, hold and manage property on a basis agreed to by members of a community in terms of a written constitution?

The Labour Tenants Act was introduced to provide for security of tenure of labour tenants and those persons occupying or using land as a result of their association with labour tenants. This Act caused some controversy and was vividly opposed by white commercial farmers.

It is clear that a comprehensive legislative programme was introduced to deal with all the aspects of the land reform process as suggested above. Thus, most of the legal aspects necessary for such a reform process have been taken care of.

\subsection{Elements of the South African land reform programme}

In this section we review the three main elements of the South African Land Reform Programme as it is administered by the Department of Land Affairs.

2 This Act resulted in many communities pooling their R15 000 grant per household and then purchasing a single piece of land. This piece of legislation had a major impact on the nature of the process of market-assisted land reform in South Africa - something that was not initially envisaged. 


\section{Restitution}

One key objective of the Land Reform Programme is the restitution of land rights to people from whom those rights were taken since 1913 as a result of racist laws. The Government's policy and procedure for land claims are based on the provisions of the Constitution and the Restitution of Land Rights Act, No. 22 of 1994. Soon after the passing of the Restitution of Land Rights Act a five-member Commission for the Restitution of Land Rights was appointed. The three-year period during which people could lodge claims according to the provisions of the Act started on 1 May 1995. A restitution claim qualifies for investigation by the Commission on Restitution of Land Rights provided that the claimant was dispossessed of a right to land after 19 June 1913 under, or for the object of, a racially discriminatory law or was not paid just and equitable compensation if expropriated under the Expropriation Act (Department of Land Affairs, 1996).

\section{Redistribution}

A Land Reform Pilot Programme was established to test various land redistribution models. The aim of the programme is to establish mechanisms for state-assisted entry into the land market for the most disadvantaged sectors of rural society. Administrative and financial structures and procedures for the pilot projects in the 36 districts chosen, have been established at national and provincial levels and are fully functional. A district office has been established in each selected Pilot District.

A large number of land redistribution requests have been received and dealt with outside the Land Reform Pilot districts. Groups of beneficiaries, the socalled common property associations, were formed in almost all the provinces. These groups pool the settlement grant of R15 000 per household in order to purchase land as a legal entity. These requests are dealt with through a process involving three stages, i.e. approval, designation and, finally, the actual transfer of land. The Screening and Priorities Committee (SPC) of the Department of Land Affairs approves the requests for land acquisition and planning grants. Virtually all of these beneficiary households were members of common property associations.

The rate of delivery in the land reform process has been slow, as will be discussed in Section 4. This is largely due to the long start-up time required for the implementation of projects. This involves assisting communities in defining their needs, the identification of land, assessment of the settlement potential of the land, the negotiation of a land price and the establishment of a 
legal entity to take ownership of the land for the beneficiaries. Not enough staff was available in the Department to undertake this work, but concerted effort have been made to fill newly established posts in the Department's provincial offices.

\section{Tenure reform}

The South African Constitution states that "a person or community whose tenure of land is legally insecure as a result of past racially discriminatory laws or practices is entitled, to the extent provided by an Act of Parliament, either to tenure which is legally secure, or to comparable redress".

Providing people with legally protected security of tenure, and recognising the various forms of tenure which exist, remains one of the biggest challenges. In 1995 the Department of Land Affairs initiated a legislative reform programme aimed at the protection of existing informal rights and allowing for alternative forms of tenure to be implemented. The Land Reform (Labour Tenants) Act and the Communal Property Associations Bill were both approved by Parliament in 1996. The Upgrading of Land Tenure Rights Amendment Bill and the Interim Protection of Informal Land Rights Bill were also passed by Parliament during 1996.

Various requests for the upgrading of Permission to Occupy (PTO) certificates in terms of Act 112 of 1991 are under investigation or have been finalised. The power to upgrade land rights in urban areas was delegated to the provinces on 24 November 1995. Requests for the upgrading of rights on tribal land will still be dealt with by the Department until the necessary policy and legal frameworks to protect the land interests of communities in tribal areas have been established.

In addition to these three core programmes of the Department of Land Affairs, considerable work has been done to address the slow pace at which land has historically been released for development. A land development and planning framework has been put in place that will expedite the release of land for priority uses - including the housing programme and land reform. The promulgation of the Development Facilitation Act in 1995 was a milestone in this regard. The establishment of its structures, the appointment of the Development Tribunal members and personnel, as well as a concerted campaign to inform stakeholders at provincial and local government level about the workings and implications of the Act is well under way (Hanekom, 1996). 
At a provincial level initiatives have been launched to enable land use for farming purposes in the urban environment. One particular problem in this regard is that urban land is often reserved for urban industry and town planning purposes. An innovative approach is to release land earmarked for future residential and industrial use, on a "temporary" basis (5 - 10 years) for farming purposes (Department of Conservation and Agriculture, 1995).

\subsection{Private land acquisition}

While some black farmers are collectively or individually making use of the gavernment grants to purchase land, a considerable number of private land transactions have already taken place without farmers making use of these measures. Recent studies ${ }^{3}$ (Kirsten, 1996 and Lyne, 1996) of deed transfers to previously disadvantaged persons through private transactions in the Northern Province and KwaZulu-Natal, revealed interesting statistics indicating the extent of private land acquisition by black farmers.

White commercial farmers (individuals and through farming companies and trusts) were, as expected, the major buyers of farmland. During 1994 and 1995 only a small number of black buyers ( $2 \%$ of the total number of buyers) were active in the land market, buying an estimated $0.1 \%$ of total farm land per annum. Although this is a negligible share of total farm land, it is indeed a beginning.

\subsection{Broadening the asset base}

Historical circumstances and impediments on contractual relationships between farm workers and owners, outgrowers and processors, etc. restricted developments of synergistic business relationships. New policy initiatives and incentives currently enable experimentation with a range of models to broaden the asset base. One way to assist the land reform process is by broadening the ownership base on commercial farms through a range of asset transfer schemes to farm workers, including for example profit sharing arrangements and equity acquisition schemes. Farm worker equity schemes include examples whereby workers could buy into an existing going concern or form partnerships to start new ventures. This may include the purchase of new land or the introduction of new enterprises on existing farms. Equity is embodied in the form of a marketable share, which allows workers to realise their capital should they wish to exit the scheme (McKenzie, 1995 and Nel, Van Rooyen \& Ngqangweni, 1995).

3 These studies were part of a research programme funded by the Development Bank of Southern Africa and a range of other institutions. 
A government/private sector task team of the Department of Land Affairs is currently developing procedures to facilitate projects to broaden the asset base. One policy proposal is to increase the flexibility of the land access grant (R15 000) paid to beneficiaries. This will allow beneficiaries to invest in existing farm enterprises as shareholders, participate in joint ventures and invest in agribusinesses. Currently $50 \mathrm{farm}$ worker equity proposals are in the pipeline and 8 are in the preparation phase. Two schemes are in early implementation. From the current evidence some preliminary conclusions can be drawn (Van Rooyen \& Ngqangweni, 1996):

- Equity sharing projects should be embarked upon as a (final) part of a process whereby farm workers were upgraded into the management systems on a farm;

- trust between owner and workers remains a vital ingredient for a successful partnership;

- high value farming allows a substantial and measurable return within an acceptable time period to participants;

- the continued support and commitment from the existing land owner/manager/farmer is necessary to allow the maintenance of farm income streams;

- clear entrance and exit rules are required; and

- business considerations should be the main value system driving deals.

A general conclusion to this strategy is that it widens the scope for redistribution within an agrarian reform context. This option, however, is only likely to be effective amongst the $(30 \%)$ top farmer groups where good business practices and enlightened labour management processes are already in progress (Ngqangweni, 1996).

\section{PROGRESS WTTH LAND REFORM IN SOUTH AFRICA}

Despite taking cognisance of the international experience in the design of the Land Reform Programme in South Africa, very slow progress has so far been made with the process of redistributing land. It seems, therefore, very unlikely that the $30 \%$ target by the end of 1999 will be achieved. In this section we first review the progress with the Land Reform Programme to date, using the 
latest statistics from the Department of Land Affairs, and then debate the reasons for the slow progress.

At the end of the 3-year period in which land claims could be lodged, a total of 26325 claims were submitted to the Commission on Restitution of Land Rights (this period has subsequently been extended until the end of 1998). Only 4252 or $16.1 \%$ of these claims were related to farmland (see Table 1).

Table 1: Land claims lodged by the end of the deadline of May 1998

\begin{tabular}{|l|r|r|r|}
\hline Province & Rural & Urban & Total \\
\hline Western Cape & 60 & 7504 & 7564 \\
Northern Cape & 108 & 566 & 674 \\
Free State & 167 & 1397 & 1564 \\
Eastern Cape & 617 & 1306 & 1923 \\
KwaZulu-Natal & 1215 & 5871 & 7086 \\
Mpumalanga & 532 & 14 & 546 \\
Northern Province & 387 & 144 & 531 \\
Gauteng & 666 & 4528 & 5194 \\
North West & 500 & 743 & 1243 \\
\hline Total & $\mathbf{4 2 5 2}$ & $\mathbf{2 2 0 7 3}$ & $\mathbf{2 6 3 2 5}$ \\
\hline
\end{tabular}

Source: Department of Land Affairs, 30 July 1998

The progress with the land redistribution programme has not been as initially expected. The way the process is currently being implemented is also contrary to all expectations, with households in most rural communities forming Common Property Associations (CPAs) by which the individual R15 000 land acquisition grant is channelled to enable communities to buy farms. This is also largely due to the fact that the Sub-division of Agricultural Land Act (Act 70 of 1970) has not been repealed, which would have enabled the sub-division of farms into affordable pieces of land. The Department of Land Affairs spent much time and effort in mobilising communities and assisting them in accessing the different government grants in acquiring land for purchase. These include, amongst others, planning grants for the settlement planring and feasibility studies for proposed land reform projects.

Concerns are increasingly being raised about the possible consequences of this approach, since the difficult institutional arrangements and possible intracommunity conflict could defy the objectives of the land reform programme. The effect of this development on agricultural growth, rural development and 
employment is not clear but initial unconfirmed reports point to possible negative outcomes.

Up to end of June 1998 the official land redistribution programme had transferred around 185384 ha to disadvantaged groups since 1994. At the end of March 1997 around 72000 ha had already been transferred and it was expected that that the trend would increase as the Department of Land Affairs continued to improve systems and procedures for delivery. At that stage it was estimated that, with the land earmarked (designated) for redistribution, tenure reform and restitution, and including estimates for other options of land reform, around $2.8 \%$ of commercial farm land in South Africa would have been transferred to less advantaged groups by mid-1998. These were very conservative estimates and were considered to be an underestimate, given that restitution cases implemented by the Department of Land Affairs were not included. However, the information provided in Table 2 shows that the land redistribution is far off the target, with only $0.225 \%$ of total farm land transferred to less advantaged South Africans.

Table 2: Progress with land reform: Estimates of land transferred to beneficiaries up to June 1998

\begin{tabular}{|c|c|c|c|}
\hline \multirow{2}{*}{ Year } & \multicolumn{2}{|c|}{ Land area transferred } & \multirow{2}{*}{$\begin{array}{c}\text { Number of } \\
\text { households } \\
\text { benefiting }\end{array}$} \\
\cline { 2 - 3 } & Hectares & $\begin{array}{c}\% \text { of total farm } \\
\text { land }\end{array}$ & 727 \\
\hline 1994 & 8085 & $0.01 \%$ & 1230 \\
\hline 1995 & 10031 & $0.012 \%$ & 6074 \\
\hline 1996 & 58918 & $0.07 \%$ & 10190 \\
\hline 1997 & 96917 & $0.117 \%$ & 1047 \\
\hline 1998 (up to June 1998) & 11433 & $0.014 \%$ & 19268 \\
\hline Total & $\mathbf{1 8 5 3 8 4}$ & $\mathbf{0 . 2 2 5 \%}$ & \\
\hline
\end{tabular}

Source: Department of Land Affairs, 30 July 1998

Based on the evidence quoted in Kirsten et al (1996) and assuming no increase in the annual number of private land purchases by black farmers, it is estimated that $0.5 \%$ can be added to the total above. Other models of transferring land ownership to less advantaged South Africans, such as equity sharing schemes, could optimistically make up around 80000 ha or $0.1 \%$. By September 1996 this had only contributed around 1000 ha to the redistribution effort. Altogether, it can optimistically be estimated that a total of $0.825 \%$ of farm land has been redistributed to less advantaged South 
Africans through a range of land reform models. The smallest part $(0.225 \%)$ was the result of the government's programme. This provides further evidence that the Government should support all possible options to redistribute land and provide a framework enabling all options to contribute to the objective of a more equitable distribution of land.

Although the land reform process in South Africa has largely adopted the ideology and guidelines as indicated earlier, the Government has said and done nothing about the supply side mechanisms of the land market. This is despite the fact that they have the idcal opportunity to do so, given the fact that 69 per cent of the book of the Agricultural Credit Board is not performing.

There is, furthermore a range of features of the administration of the Land Reform Programme that violates the design criteria set out initially. The large bureaucracy that emerged and the length of time that is required to get an application for a land reform grant approved are astonishing. From the time an individual or a group of households has shown interest in acquiring a specific piece of land, a lengthy process of consultation and planning takes place which drains a tremendous amount of Departmental resources. An application for accessing the land redistribution grant needs to go through a number of phases as shown in Table 3 . There is clearly significant interest in acquiring land, but it is highly likely that the communities who registered interest in 1997 would only be the proud owners of their land by the end of 1999 or early 2000 - a period of two to three years. The ideology behind the market-assisted process was to minimise the role of Government. This has clearly not been achieved and, as shown here, is largely responsible for the slow progress with land redistribution. The excessive centralisation of land reform can be considered as the main reason for the poor performance and the slow delivery of land to beneficiaries.

Table 3: Land transfer. Summary of redistribution projects in the pipeline (ha farm land)

\begin{tabular}{|c|c|c|c|}
\hline Year & $\begin{array}{c}\text { Feasibility and } \\
\text { designation phase }\end{array}$ & $\begin{array}{c}\text { Project approval } \\
\text { phase }\end{array}$ & $\begin{array}{c}\text { Registration of } \\
\text { Interest }\end{array}$ \\
\hline 1994 & 17019 & 69341 & 73389 \\
\hline 1995 & 10969 & 123209 & 200632 \\
\hline 1996 & 99310 & 253091 & 539634 \\
\hline 1997 & 67882 & 374693 & 560378 \\
\hline 1998 (Up to June) & 80503 & 11425 & 4706 \\
\hline
\end{tabular}

Source: Department of Land Affairs, 30 July 1998 
The continued obsession with legislation and peripheral issues, such as labour tenants etc, which takes up much time and creates less support for the land reform process can also be considered as contributing factors. Although these issues are necessary and part of the land reform program, they are peripheral and do not contribute to the central process of redistributing the land.

The Department of Land Affairs also has an excessive focus on land acquisition. As seen above, most of the efforts of the Department are geared to assisting communities through the long process in acquiring land. There is very little if any focus on farm development, which could negatively affect the sustainability and success of the land reform programme in South Africa. The lack of co-operation between the provincial departments of Agriculture and Land Affairs also contributes to the lack of emphasis on farm development.

\section{CONCLUSIONS: WHAT WENT WRONG?}

The South African Land Reform Programme was established in 1994 as an integral part of a comprehensive programme of economic reconstruction. The Programme has strong political acceptability and legitimacy, with a consensus across the spectrum of political opinion that the programme is necessary. However, it falters on the following points:

- The speed of implementation of the Programme is slow due to a combination of excessive bureaucracy and over-centralisation of the process, which render the Programme ineffective.

- Economic viability of the farm models has not been adequately addressed in that livelihood options available to resettled households generally indicate that they have insufficient land size and quality to provide at least the target income. Moreover, other assistance and infrastructure necessary to generate the income is not readily available to beneficiaries.

- There is no clear definition of the role that the public sector can and must play, and what should best be left to the non-governmental sector. International evidence has shown conclusively that such programmes that have relied entirely on the public sector in the belief that it is the only one capable of maintaining integrity, delivering services, determining needs, and managing the process, have failed.

- The need for additional services - infrastructure, markets, incentives, health - to be considered and access provided, has not received adequate attention. These considerations are necessary both to sustain higher 
productivity subsequent to reform, and to include others who may not benefit from the direct provision of land.

- Changes to the legal environment have been aimed at establishing the rights of particular marginalised groups. However, some major impediments have not been addressed yet, for example the Sub-division of Agricultural Land Act which is still in place (although it will in all probability be repealed before the end of 1998). Research has shown that this particular legislation is a major impediment to land reform within a market-assisted approach, and will in all probability cause such an approach to fail.

In conclusion, it seems that while the Land Reform Programme started out on a sound basis, it has become an over-centralised and bureaucratic process in which the public sector tries to do everything. Notwithstanding the tedious planning process, the planning around farm models and appropriate support to beneficiaries, once they have acquired land under the Programme, are inadequate. Moreover, important pieces of legislation impeding land reform within a market-assisted framework, in particular the Subdivision of Agricultural Land Act, have not been repealed.

Throughout the planning phase of the land reform programme it was continuously stated that the Government should stay out of the process as far as possible, since the bureaucracy is not geared for a process of rapid land reform. The Government should only provide the framework (legislative and otherwise) within which the process should take place and should not become a player in the process. Unfortunately in the South African case the Government has become the major player. In the initial design of the land reform programme it was envisaged that Government would empower and enable farmers in financial difficulty to sell off parts of their farms to individual black farmers. Due to the legal impediments discussed earlier, this has not been possible.

Against this background, it is not surprising that the South African Land Reform Programme has not lived up to expectations and that it is doomed to fail in obtaining the redistribution targets. More importantly, the objectives of increased efficiency and equity, increased growth and poverty reduction appear unlikely to be achieved. It is also doubtful whether the program, as currently implemented, has the ability to create the class of independent and viable small-scale family farms that were initially envisaged. It further seems that the vision of South African agriculture of a more diversified farm structure centred around competitive commercial, owner-operated, family farms (Van Zyl, 
1996), has only a very remote chance of being realised. The challenge is thus to find ways and means to put the programme of redistributing farm land back on track.

\section{REFERENCES}

BINSWANGER, H. (1996). The political implications of alternative models of land reform and compensation. In: Van Zyl, J., Kirsten, J.F. and Binswanger, H.P. (eds.) (1996). Agricultural land refom in South Africa: Policies, Markets and Mechanisms. Oxford University Press, Cape Town.

CARTER, M.R. \& MESBAH, D. (1993). Can Land Market Reform mitigate the exclusionary effects of rapid agro-export growth? World Development, 21 (7):1058-1100.

CHRISTIANSEN, R. (1996). Overview of land reform issues. In: Van Zyl, J., Kirsten, J.F. and Binswanger, H.P. (eds.) (1996). Agricultural land reform in South Africa: Policies, Markets and Mechanisms. Oxford University Press, Cape Town.

DEPARTMENT OF CONSERVATION AND AGRICULTURE: GAUTENG PROVINCE. (1995). Towards and urban agriculture strategy. Unpublished Report, Pretoria.

DEPARTMENT OF LAND AFFAIRS. (1996). Annual Report, 1995. RP94/1996, Government Printer, Pretoria.

DEPARTMENT OF LAND AFFAIRS. (1998). Unpublished information. Monitoring and Evaluation Unit, Pretoria.

HANEKOM, D. (1996). Address to Senate to introduce the 1996/97 Appropriation Bill of the Departinent of Land Affairs. 12 June 1996.

KINSEY, B. \& BINSWANGER, H. (1996). Characteristics and performance of settlement programmes: a review. In: Van Zyl, J., Kirsten, J.F. and Binswanger, H.P. (eds.) (1996). Agricultural land reform in South Africa: Policies, Markets and Mechanisms. Oxford University Press, Cape Town.

KIRSTEN, J.F. \& VAN ZYL, J. (1996). The contemporary agricultural policy environment: undoing the legacy of the past. In: Van Zyl, J., Kirsten, J.F. and Binswanger, H.P. (eds.) (1996). Agricultural land reform in South Africa: Policies, Markets and Mechanisms. Oxford University Press, Cape Town. 
KIRSTEN, J.F., VAN ROOYEN, J. \& NGQANGWENI, S. (1996). Progress with different land reform options in South Africa. Agrekon 35(4):

KLUG, H. (1996). Bedevilling agrarian reform: the impact of past, present and future legal frameworks. In: Van Zyl, J., Kirsten, J.F. and Binswanger, H.P. (eds.) (1996). Agricultural land reform in South Africa: Policies, Markets and Mechanisms. Oxford University Press, Cape Town.

LUND, S. (1996). An overview of the land reform pilot programme. In: Van Zyl, J., Kirsten, J.F. and Binswanger, H.P. (eds.) (1996). Agricultural land reform in South Africa: Policies, Markets and Mechanisms. Oxford University Press, Cape Town.

LYNE, M. (1996). Estimates of land transferred to less advantaged owners. Unpublished typescript. Department of Agricultural Economics, University of Natal, Pietermaritzburg.

MBONGWA, M., VAN DEN BRINK, R. \&. VAN ZYL, J. (1996). Evolution of the agrarian structure in South Africa. In: Van Zyl, J., Kirsten, J.F. and Binswanger, H.P. (eds.) (1996). Agricultural land reform in South Africa: Policies, Markets and Mechanisms. Oxford University Press, Cape Town.

MCKENZIE, C. (1995). Providing access to commercial farming in the Westem Cape: An analysis of the fiscal performance of alternative farm models. Unpublished typescript, DBSA, Halfway House.

NEL, P.R.C., VAN ROOYEN, C.J. \& NGQANGWENI, S. (1995). Farm worker participation Schemes: Conditions for success. Agrekon, 34(4):183-189.

NGQANGWENI, S. (1996). Farm worker participation schemes in the context of agrarian reform in South Africa. Unpublished Masters Dissertation, University of Pretoria.

VAN ROOYEN, C.J. \& NGQANGWENI, S. (1996). Comments on farm worker participation schemes. Paper presented at the Southern African Regional Business Forum. Harare, March, 27 - 29.

VAN ZYL, J. (1996). A vision for Agriculture and Management of the Transition. In: Van Zyl, J., Kirsten, J.F. and Binswanger, H.P. (eds.) (1996). Agricultural land reform in South Africa: Policies, Markets and Mechanisms. Oxford University Press, Cape Town. 
VAN ZYL, J., KIRSTEN, J.F. \& BINSWANGER, H.P. (eds.). (1996). Agricultural land reform in South Africa : Policies, markets and mechanisms. Oxford University Press, Cape Town. 